усвідомленій діяльності учнів (виконання домашнього завдання, поведінка в класі, виконання суспільних доручень), що сприяє ефективному формуванню і розвитку їхніх індивідуальних якостей (розумові, морально-етичні тощо).

Характеризуючи моральне формування особистості, Н. Бордовськая і А. Реан відзначили, що процеси виховання і навчання невід'ємні однин від одного і спрямовані на людину одночасно, що ускладнює можливість виокремити елементи впливу освітніх і виховних дій на розвиток особистості. Проведений нами аналіз наукової і психолого-педагогічної літератури стосовно розуміння та організації процесів навчання і виховання свідчить, що в них $є$ свої особливості. Теорія i методика виховання є розділами загальної педагогіки, які містять принципи і методи, цілі і зміст процесу виховання [9].

Моральне формування як складник виховного процесу спрямоване на зміну психічного стану людини, світогляду і свідомості, знань і способу діяльності особистості іiі ціннісних орієнтацій. Моральне формування дитини як складний процес залежить від багатьох факторів (місце проживання, суспільні цінності; сімейні стосунки, стосунки у школі, мистецтво і засоби масової інформації).

\title{
Література
}

1. Азаров Ю. П. Методика воспитательной работы: учеб. пособие для студентов пед. ин-тов / Ю. П. Азаров, Л.М.Байтенова, Е. П. Белозерцев и др.; под ред. Л. И. Рувинского. - М. : Просвещение, 1989. - 335 с. 2. Афанасьев В. Г. Человек в управлении обществом / В. Г. Афанасьев. - М. : 1977. - 382 с. З. Бордовская Н. В. Педагогика: [учебник для вузов] / Н. В. Бордовская, А. А. Реан. - СПб : Издательство «Питер», 2000. - 304 с. 4. Волкова Н. П. Педагогіка : посіб. для студ. вищих навч. закл. / Н. П. Волкова. - К. : ВЦ «Академія», 2001. - 576 с. 5. Концепція загальної середньої освіти (12-річна школа)// Книга історії, етики, основ правознавства : довідково-метод. вид. / упоряд. : Р. І. Свтушенко, О. В. Галєгова. -[вид. 2-е, доповн.]. - Харків : ТОРСІНГ ПЛЮС, 2006. - С. 72-92. 6. Кузьменко Т. М. Соціологія. : навч. посіб. / Т. М. Кузьменко. - К. : Центр учбової літератури, 2010. 320 c. 7. Лукашевич М. П. Соціологія. Загальний курс : [підручник] / М. П. Лукашевич, М. В. Туленков. - [2-е вид.]. - К. : Каравела, 2011. - 408 с. 8. Макаренко А. О воспитании / А. О. Макаренко. - М. : Политиздат, 1990. - 415 с. 9. Положення про загальноосвітній навчальний заклад // Освіта України: нормативноправові документи (до II Всеукр. з'їзду працівників освіти). К, 2001. - С. 138-183. 10. Соціологія : підруч. для студ. вищ. навч. закл. / В. І. Волович, М. І. Горлач, В. Г. Кремень та ін. -[6-те вид.]. - К. : Центр учбової літератури, 2009. - 808 с.

Ольга Майба

\section{СТРУКТУРА ФОРМУВАННЯ ХРИСТИЯНСЬКИХ ПРАВОСЛАВНИХ ЦННОСТЕЙ ДІТЕЙ МОЛОДШОГО ШКІЛЬНОГО ВІКУ У ПРОЦЕСІ ХОРОВОї ДІЯЛЬНОСТІ}

Майба О. К. Структура формування християнських православних цінностей дітей молодшого шкільного віку у процесі хорової діяльності.

У статті розглядається структура формування християнських православних цінностей дітей молодшого шкільного віку у процесі хорової діяльності. Аналізуються зміст виокремлених компонентів, які у тісному взаємозв'язку поступово готують дитину до найвищого рівня прояву формування християнських православних цінностей через церковний спів в умовах недільної школи. 
Ключові слова: християнські православні цінності, церковний спів, компонент, діти молодшого шкільного віку, хорова діяльність,недільна школа.

Майба О. К. Структура формирования христианских православных ценностей детей младшего школьного возраста в процессе хоровой деятельности.

В статье рассматривается структура формирования христианских православных ценностей детей младшего школьного возраста в процессе хоровой деятельности. Анализируются содержание выделенных компонентов, которые в тесной взаимосвязи постепенно готовят ребенка к самому высокому уровню проявления формирования христианских православных ценностей через церковное пение в условиях воскресной школы.

Ключевые слова: християнские православные ценности, церковное пение, компонент, дети младшего школьного возраста, хоровая деятельность, воскресная школа.

Mayba O. K Structure formation orthodox christian values of primary school children in the choral activities.

The article describes the structure of the Christian Orthodox values of primary school children in the process of choral activities.It analyzes the content of the selected components that are in close relationship gradually prepare the child to the highest level of manifestation of the Christian Orthodox values through church singing in a Sunday school.

Key words: early Christian Orthodox values, church singing, component, children of primary school age, choral activities, Sunday school.

Християнські православні цінності виконують регулятивну, оцінну функцію, мотивують життєдіяльність людини та допомагають здійснювати вибір форм і методів поведінки в життєво-важливих ситуаціях. Особливого значення проблема формування християнських православних цінностей набуває в молодшому шкільному віці, коли пробуджується інтерес до свого внутрішнього світу, що виявляється в самопоглибленні, розмірковуванні над власними переживаннями, думками. Відповідно виникає завдання такої цілісної організації освітнього простору, у якому б дитина молодшого віку знайшла відповідну педагогічну підтримку в складному процесі становлення та розвитку духовного світу і християнських православних цінностей. Тому формування християнських православних цінностей дітей молодшого шкільного віку необхідно розглядати як одне 3 найважливіших завдань освітнього, культурного й духовного розвитку та виховання нового покоління. У соціокультурній ситуації музично-педагогічна освіта покликана розробляти прогресивні форми навчання, створювати нові методики 3 метою оновлення навчально-виховного процесу i підвищення його ефективності. Необхідність дослідження формування християнських православних цінностей у дітей молодшого шкільного віку в процесі хорової діяльності усвідомлюється як актуальна проблема сучасної музичної педагогіки. Найбільш сприятливий для формування християнських цінностей і традицій засобами музики є молодший шкільний вік, оскільки саме в цей період закладається базова культура людини, фундамент усіх видів мислення.

Однією із соціально-виховних структур, що впливає на формування християнських православних цінностей дітей молодшого віку, є недільна школа. Сучасна недільна школа ставить нові проблеми перед парафіями, усіма, хто так чи інакше, пов'язаний з просвітницько-освітньою діяльністю Церкви. Духовно-моральне виховання $є$ одним з найважливіших аспектів у роботі недільної школи, в основі якої 
лежать православні традиції, що поєднують тисячолітній досвід духовно-морального життя народу, православної педагогіки, народної творчості, науки, мистецтва, етичного і естетичного змісту [1, с. 65].

Культурно-освітня діяльність недільної школи забезпечує збереження, передачу, відтворення і розвиток національної й світової культури, а також сприяє встановленню духовного взаємозв'язку між особистістю та народом, вихованню іï цінностей, як своїх власних. Ці завдання виконуються у процесі формування цінностей саме в контексті християнської світової культури, а також у процесі розкриття творчого потенціалу дітей через залучення їх до світової літератури, образотворчого мистецтва, а також вокально-хорового співу. «Ефективність виховної ролі хорової музики, а також спрямованість і характер іiї соціального впливу $\epsilon$ найважливішими критеріями, що визначають суспільну значимість хорового мистецтва і його місця в системі духовно-культурних цінностей» [6].

Музика займає особливе, пріоритетне місце в молодшому шкільному віці. Музика - не тільки носій духовних цінностей, збережених людством, а й мова духовного спілкування, яку дитині необхідно опанувати. Залучення до загальнолюдського духовного досвіду, вираженому в музиці свого народу та інших народів світу, відбувається в хоровій діяльності, у процесі створення особистістю індивідуального варіанту музичного образу в інтонаційно-мистецькому спілкуванні 3 музичним твором [3, с. 30]. «Хоровий спів- найбільш доступний вид музичного виконавства, адже голос- «інструмент», даний людині від народження, удосконалюється разом 3 його ростом і розвитком. А виховання співочих навичок $\epsilon$ одночасно і вихованням людських почуттів і емоцій»[2, с. 10]. Але, щоб досягти високого рівня вокального виконання у церковному хорі, необхідна кропітка музична вокально-педагогічна робота зі співаками, котрих виховувати краще 3 молодшого шкільного віку.

Вивчення та аналіз сучасних досліджень та педагогічних праць 3 проблем музичного навчання молодших школярів (О. Грисюк, О. Коваль, М. Матківська, О. Нижник, О. Олексюк, Л. Михайлова, Л. Прокоф’єва, В. Процюк, В. Рагозіна, О. Ростовський, О. Чайковська, К. Шевчук та ін.) дає підстави для узагальнення таких вимог до розробки змістової структури нашого дослідження: об'єктивність відображення ознак, притаманних досліджуваному предмету; відображення суттєвих ознак предмета; стійкість та постійність ознак; зв'язок 3 цілями, завданнями та змістом конкретного педагогічного дослідження.

Результати наших спостережень за виступами i процесом навчання співу дитячих церковних хорів в умовах недільної школи показують, що рівень вокальнохорового розвитку молодших школярів низький. Особливості навчально-виховного процесу, а також музичного матеріалу становлять специфіку навчання у православних школах. Це потребує внесення певних змін у зміст і структуру вокально-хорової діяльності дітей молодшого шкільного віку в умовах недільної школи

Отже, метою статmі $є$ визначити структуру формування християнських православних цінностей дітей молодшого шкільного віку у процесі хорової діяльності.

Формування християнських православних цінностей молодших школярів у процесі хорової діяльності сприяє більш повному використанню мотиваційного, ціннісного, когнітивно-пізнавального, діяльнісного i творчого потенціалу дітей. Найбільш ефективною формою у цьому процесі, на нашу думку, виступає позашкільний педагогічний процес, який створює умови для повного та ефективного навчання дітей навичок вокально-хоровому співу та сприяє формуванню 
християнських православних цінностей молодших школярів. Ми вважаємо, що змістову структуру формування християнських православних цінностей дітей молодшого шкільного віку в процесі хорової діяльності складає такі компоненти,як: мотиваційно-ціннісний, когнітивно-пізнавальний, діяльнісно-творчий.

Мотиваційно-ціннісний компонент засвідчує високий ступінь сформованості мотивів та інтересу до християнських цінностей через залучення до церковного співу, націленість на пізнання пісенних традицій та співацьке самовдосконалення і дозволяє здійснювати активно-мотиваційне забезпечення цілісного опанування українськими християнськими традиціями та трансформацію їх в українську освітньо-виховну систему цілерегулювання самовизначення. Реалізація змісту такого компоненту зумовлює ціннісну спрямованість естетичних емоційно-почуттєвих мотивів дітей переживати й співпереживати прекрасне в мистецтві, емоційно відгукуватися на зміст вокальних творів у процесі формування християнських цінностей.

Дослідження показали, що мотивом, тобто головною рушійною силою в хоровій діяльності дітей молодшого шкільного віку в умовах недільної школи $є$ інтерес до церковної музики, 3 одного боку, і вокально-хорової діяльності, - 3 іншого. Він виявляється як необхідність сприймання, розуміння, виконання церковних творів, передачі необхідних співацьких навичок, як потяг до глибоких емоційних переживань, бажання передати дітям навички та вміння вокального-хорового мистецтва, навчити їх розуміти й любити духовну музику.

На думку Т. Купріна, поняття «мотивація» «являє собою внутрішню психологічну активність, що організовує та планує діяльність і поведінку, в основі яких лежить необхідність задоволення потреби. В процесі мотивації потреба дістає одну зі своїх суттєвих властивостей - предметність... Набуття потребою свого предмета, іiі опредметнювання і зумовлює перетворення потреби на певний мотив діяльності» $[4$, с. 389, 390]. Щодо предмету нашого дослідження, то пріоритетними ми визначаємо естетичні потреби, які безпосередньо пов'язані з чуттєво-емоційною сферою дитини, та мотиви самовираження, самоствердження особистісних досягнень. Естетичні потреби ми розглядаємо, як зацікавленість молодшого школяра в церковному співі, вихідний момент створення або засвоєння естетичного у різноманітних формах хорової діяльності. Серед естетичних потреб особливої уваги заслуговують музичні потреби, природу яких детально розглянув Г. Тарасов. Як зауважує науковець, потреби виступають у ролі стимулятора емоційно-ціннісної сфери індивіда, тим самим показуючи на зв'язок формування музичних потреб та ціннісних орієнтацій [7, с. 52].

Отже, мотиваційно-ціннісний компонент забезпечує стабільний інтерес дітей до вокально-хорової діяльності.

Когнітивно-пізнавальний компонент включає систему знань із музичного мистецтва, здатність мислити образами, розмаїття ідей, музичний смак; емоційний передбачає наявність почуттєвих реакцій під час слухання та виконання музики (від простого задоволення до музичного катарсису); Прояви когнітивного компоненту ми розглядаємо з позиції використання дітьми знань, умінь і навичок у галузі вокальної, хорової діяльності, гри на музичних інструментах, наявності в дітей уяви, яка б сприяла створенню ними музичних образів, проявів адекватної оцінки та самооцінки. Процес розвитку музичних здібностей досить складний та довготривалий i знаходиться у прямій залежності від розумової, слухової, виконавчої діяльності дитини. Це перегукується 3 твердженням С. Рубінштейна: «Розвиток людини - це ... формування iі здібностей» [5, с. 138].

Основна роль належить системним знанням (про церковний музичний матеріал, 
побудову голосового апарату, правильну співацьку настанову, співацький голос, прийоми його розвитку, правила інтонування, різноманітні музичні інструменти, техніку гри на них), які спираються не тільки на теоретичну діяльність, але й розвивають індивідуальний музичний досвід дітей молодшого шкільного віку. Знання лежать в основі формування вмінь і навичок, через які здійснюється розкриття творчих здібностей. Оволодіння основним теоретичним та практичним матеріалом знань, широка обізнаність у царині церковного співу визначає високий рівень інтелектуального розвитку дитини, який $\epsilon$ обов'язковою умовою формування християнських православних цінностей у дітей молодшого шкільного віку.

Важливим компонентом у формуванні християнських цінностей дітей молодшого віку у процесі хорової діяльності $\epsilon$ діяльнісно-творчий, який включає навички та вміння, що виступають як інструмент реалізації вокально-хорових знань на рівні індивідуальної, групової чи колективної діяльності. Колективна діяльність буде виконана повноцінно, якщо дитина оволоділа навичками виконання окремих дій, про що зазначають дослідники в галузі педагогіки та психології (П. Блонський, О. Зак, О. Запорожець, К. Платонов, В. Сластьонін та ін.). Діяльнісно-творчий компонент визначає рівень хорової діяльності дитини, що знаходить своє вираження у творчому відтворенні духовної музики та у подальшій оцінці свого продукту праці. Б.Теплов підкреслює, що необхідно залучати до творчої діяльності всіх дітей без винятку, що дуже корисно для загального розвитку, є цілком природнім для дитини і відповідає їі потребам та можливостям [8, с. 134].

Слід підкреслити, що для творчої діяльності дитини необхідною є наявність основних музичних здібностей, характеристику яких дають Б. Теплов, Н. Ветлугіна, В. Фролкін та інші дослідники. Основними музичними здібностями ці вчені називають ладове чуття, здатність до слухового уявлення, музично-ритмічне чуття. При цьому комплекс музичних здібностей виявляється по-різному, в залежності від виду музичної діяльності. У вокально-хоровій діяльності велике значення має комплекс музичних здібностей таких як: наявність слуху, голосу, відчуття ритму. В умовах недільної школи до складу дитячого хорового колективу приходять діти не без необхідного комплексу музичних здібностей, але 3 великим бажанням навчитися співати церковні твори і брати участь у різних формах хорової діяльності.

Отже, діяльнісно-творчий компонент виражає здатність до виконання церковних творів на основі здобутих знань та вмінь. Він включає сукупність навичок і умінь, що дозволяє творчо реалізовувати та презентувати християнські православні традиції $\mathrm{i}$ цінності через залучення до церковного співу.

Ми проаналізували всі вищеназвані компоненти й визначили, що формування християнських православних цінностей дітей молодшого шкільного віку в процесі хорової діяльності - це органічна та суттєва частина духовної культури особистості, яка становить собою цілісне структурне утворення специфічних компонентів (мотиваційно-ціннісного, когнітивно-пізнавального, діяльнісно-творчого), які розвиваються у процесі роботи над церковними творами і реалізовуються в хоровій діяльності за допомогою відповідних знань, умінь та навичок. Для активного засвоєння молодшими школярами християнських православних цінностей в єдності мотиваційно-ціннісного, когнітивно-пізнавального та діяльнісно-творчого необхідно спрямовувати виховну роботу таким чином, щоб дитина відчувала себе впевненою, захищеною, щасливою, переконаною в тому, що иї люблять, задовольняють іiі розумні потреби. Цілісність в осмисленні поняття «християнські православні цінності» досягається завдяки широкому використанню церковної і музичної літератури, образотворчого матеріалу, а також власному творчому використанню навколишньої 
дійсності.

Отже, структура формування християнських православних цінностей дітей молодшого віку складається 3 трьох компонентів, які знаходяться у тісному взаємозв'язку, i, поступово випливаючи один з одного, готують дитину до найвищого рівня прояву формування християнських православних цінностей у процесі хорової діяльності. Перспективи подальших досліджень пов'язані 3 розробкою моделі формування християнських православних цінностей дітей молодшого шкільного віку у процесі хорової діяльності.

\section{Література}

1. Абраменкова В.В. Сорадость и сопереживание в детской картине мира / В. В Абраменкова. - М., 1999. - 70 с. 2. Бечак Б. А. Виховання мистецтвом. - М. : Просвещение, 1981. 3. Красильников І. М. Музичне мистецтво і педагогіка завтра / I. М. Красильников, М. А. Крюков // Музика в школі. - 2000. - № 3. - С. 34-36. 4. Потребісно-мотиваційна підсистема // Психологія : підручник / Ю. Л. Трофімов, В. В. Рибалка, П. А. Гончарук та ін. [за ред. Ю. Л. Трофімова]. - 4-те вид., стереотип.]. - К. : Либідь, 2003. - 560 с. 5. Рубинштейн С. Л. Проблема способностей и вопросы психологической теории: Тезисы докладов на I съезде общества психологов. - М., 1959. - Вып. 3. - С. 37-39. 6. Скрябіна Н. І. Хоровий спів у вирішенні задач музично-естетичного виховання / Н. І. Скрябіна // Музично-естетична освіта в соціокультурному розвитку особистості: тез. доп. науч. практич. конф., 25-26 лютого 1999р., м Ек. / Урал. держ. пед. ун-т, Ек ., 1999]). 7. Тарасов Г. С. Проблема духовной потребности (на материале музыкального восприятия) / Г. С. Тарасов. - М. : Наука, 1979. - С. 78-84. 8. Теплов Б. М. Психология музыкальных способностей. Избр. тр.: В 2 т. - М. : Педагогика, 1985, Т. 1- С. 42-222.

\section{ШЛЯХИ ОРГАНІЗАЦЇ̈ ВЗАЕМОДІЇ ВЧИТЕЛЯ Й УЧНІВ У НАВЧАЛЬНО-ВИХОВНОМУ ПРОЦЕСІ ПОЧАТКОВОЇ ШКОЛИ}

Марків В. М. Шляхи організації взаємодії вчителя й учнів у навчальновиховному процесі початкової школи.

У статті розглядаються способи організації взаємодії вчителя й учнів у навчально-виховному процесі початкової школи, переосмислюється мета і результат освітнього процесу, модернізація його змісту.

Ключові слова: нова парадигма освіти, педагогічна взаємодія, спілкування, співробітництво, модернізація, оптимізація технології.

Маркив В. Н. Пути организации взаимодействия учителя и учеников в учебновоспитательном процессе начальной школы.

В статье рассматриваются способы организации взаимодействия учителя и учеников в учебно-воспитательном процессе начальной школы, переосмысливание цели и результата учебного процесса, модернизация его содержания.

Ключевые слова: новая парадигма образования, педагогическое взаимодействие, общение, сотрудничество, модернизация, оптимизация технологии.

Markiv V. N. Ways of organization of co-operation of teacher and students in teaching-educational process in primary school.

In the article the methods of organization of co-operation of teacher and students are 